\title{
COMPLIANCE WITH IFRS REQUIRED DISCLOSURE AND ANALYSTS' FORECAST ERRORS: EVIDENCE FROM BRAZIL1
}

\author{
Edilene Santana Santos2 \\ Flávia Almeida Morato da Silva3 \\ Hsia Hua Sheng4 \\ Mayra Ivanoff Lora5
}

- Artigo recebido em: 07/02/2017 -• Artigo aceito em: 02/01/2018 •- Segunda versão aceita em: 11/04/2018

\begin{abstract}
We analyze the relationship between analysts' earnings forecast errors and Brazilian listed firms' compliance with International Financial Reporting Standards (IFRS) required disclosure. Through analysis of a panel data, we examine whether the variance in the Brazilian firms' disclosure compliance levels in the Notes to Financial Statements for 2010 and 2012 affects analysts' earnings forecast errors for 2011 and 2013, respectively, finding a significant negative relationship between these variables. By performing a compliance level analysis per firm, our study considers whether and to what extent firms effectively disclose as required by IFRS (as "IFRS serious adopters"), distinguishing them from firms that mere formally adopt IFRS (as "IFRS label adopters"), without effectively complying with it. Following other studies, we use four alternative models to measure the disclosure compliance level per firm, and we do not find significant improvement in the firms' disclosure levels from 2010 to 2012, except if we use the most tolerant model. By this approach, our research contributes to clarify the impact of IFRS adoption on analysts' forecast accuracy, as other studies that use only binary variables (analysts' forecasts before and after IFRS adoption) have found contradictory results. Our findings confirm other studies on the international accounting convergence in other countries, emphasizing that compliance is at least as important as the simply formal IFRS adoption. This corroborates the relevance of enforcement mechanisms to induce
\end{abstract}

\footnotetext{
${ }^{1}$ Agradecemos à Fapesp o apoio financeiro à realização desta pesquisa e sua apresentação no Congresso USP de Controladoria e Contabilidade de 2016 e no American Accounting Association Annual Meeting de 2016.

2 Doutora em Controladoria e Contabilidade pela FEA-USP. Professora da Escola de Administração de Empresas de São Paulo da Fundação Getúlio Vargas - FGV-EAESP. Rua Itapeva, 474, $8^{\circ}$ andar. CEP: $01332-000$ - São Paulo - SP - Brasil. E-mail: edilene.santos@fgr.br.

3 Mestre em Economia pela FGV-EESP. Rua Itapeva, 474, $8^{\circ}$ andar. CEP: 01332-000 - São Paulo - SP - Brasil. E-mail: fmorato@gmail.com.

4 Doutor em Administração pela FGV-EAESP. Professor da Escola de Administração de Empresas de São Paulo da Fundação Getúlio Vargas - FGV-EAESP. Rua Itapeva, 474, $8^{\circ}$ andar. CEP: 01332-000 - São Paulo - SP - Brasil. E-mail: hsia.sheng@fgv.br.

5 Doutora em Estatística pela USP. Professora da Escola de Economia de São Paulo da Fundação Getúlio Vargas - FGV-EESP. Rua Itapeva, 474, $8^{\circ}$ andar. CEP: 01332-000 - São Paulo - SP - Brasil. E-mail: mayra.lora@fgv.br.
} 
firms to better comply with IFRS, thus to better attain the economic benefits expected from its adoption.

Key Words: IFRS, Compliance, Mandatory Disclosure, Analysts' Forecast Errors, Brazil.

\section{CUMPRIMENTO DA EVIDENCIAÇÃO REQUERIDA PELAS IFRS E ERROS DE PREVISÃO DE ANALISTAS: EVIDÊNCIAS DO BRASIL}

\section{RESUMO}

Nós analisamos a relação entre os erros de previsão de analistas e o cumprimento da evidenciação requerida pelas International Financial Reporting Standards (IFRS) pelas empresas brasileiras listadas. Mediante análise de dados em painel, analisamos se a variação no nível de evidenciação nas Notas Explicativas de 2010 e 2012 afeta os erros de previsão de analistas para 2011 e 2013, respectivamente, encontrando uma relação negativa significativa entre essas variáveis. Ao calcular o nível de cumprimento por empresa, este estudo considera se e em que extensão as empresas realmente evidenciam as informações requeridas pelas IFRS (como "IFRS serious adopters"), distinguindo essas empresas daquelas que adotaram as IFRS apenas formalmente (como "IFRS label adopters"), sem efetivamente cumpri-las. Seguindo outros estudos, nós usamos quatro modelos alternativos para mensurar o nível de cumprimento por empresa, e não encontramos melhoria significativa no nível de evidenciação de 2010 para 2012, exceto se usarmos o modelo mais tolerante. Ao adotar essa abordagem, nossa pesquisa contribui para esclarecer o impacto da adoção das IFRS na acurácia de previsão dos analistas, já que outros estudos que usaram apenas variáveis binárias (previsões de analistas antes e depois da adoção das IFRS) encontram resultados contraditórios. Nossos resultados confirmam estudos em outros países sobre a convergência contábil internacional, enfatizando que o cumprimento é pelo menos tão importante quanto a adoção das IFRS em si. Isso corrobora a relevância dos mecanismos de enforcement para induzir as empresas a cumprir efetivamente as IFRS, de forma a melhor obter os benefícios econômicos esperados com sua adoção.

Palavras-Chave: IFRS, Cumprimento, Evidenciação obrigatória, Erro de previsão de analistas.

\section{INTRODUCTION}

Accounting provides information on firms' transactions to enable rational resource allocation decisions by the users. If the reported information is reliable and useful, scarce resources are optimally allocated; conversely, resource allocations are less than optimal when information is less reliable and useful (CHOI, FROST, and MEEK, $2011)$.

Brazil has adopted the full IFRS in 2010, after a transition period, as per Law 11,638 , effective on 28 of December of 2007; since then IFRS is mandatory for both 
all Brazilian listed firms - a sample from them is examined in this study - and all nonlisted big corporations. As a main change brought by IFRS, Brazilian accounting practice now has to focus on the economic essence of business rather than on previous legal formalism. This promises relevant implications on improving the quality of accounting information for the users.

Convergence to IFRS, by establishing worldwide standardized accounting principles, enables greater comparability between firms' disclosed information among jurisdictions, and can lead to an increase in disclosure quality, thus reducing both information asymmetry between firms and investors and the cost of capital for companies (LEUZ and VERRECCHIA, 2000).

In this context, several studies (LANG and LUNDHOLM, 1996; HUSSAIN, 1997; BARRON, KILE, and O'KEEFE, 1999; HOPE, 2003a, 2003b; HODGDON, TONDKAR, HARLESS, and ADHIKARI, 2008; GLAUM, BAETGE, GROTHE, and OBERDORSTER, 2013; PESSOTI, 2012; GATSIOS, 2013) seek to evaluate whether the adoption of an international recognized standard (US GAAP or IFRS) leads to enhanced disclosure to the market and, consequently, improves the accuracy of the analysts' earnings forecasts. Although the conclusions of these studies are not totally convergent, it is in general expected that the improvement on the quality of the accounting information disclosed can reduce the analysts' earnings forecast errors.

In Brazil, two studies evaluate the influence of the IFRS adoption on analysts' forecasts accuracy (PESSOTTI, 2012; GATSIOS, 2013), finding diverging results. However, these studies use only binary variables, comparing analysts' forecasts before and after IFRS adoption. Indeed, by adopting this approach, these studies neglect evidence from other studies finding that numerous Brazilian firms did not adequately comply with IFRS required disclosure (SANTOS, PONTE, and MAPURUNGA, 2014; MAPURUNGA, PONTE, COELHO, and MENESES, 2011), which can jeopardize the impact perception of IFRS adoption.

The present research aims to verify the influence of the level of compliance with IFRS disclosure requirements on analysts' forecasts accuracy. In fact, the compliance level analysis enables to distinguish whether and to what extent firms effectively disclose as required by IFRS (as "IFRS serious adopters") from firms that mere formally adopt the IFRS (as "IFRS label adopters") without effectively complying with it (see DASKE, HAIL, LEUZ, and VERDI, 2013). Thus, unlike other studies based on de jure IFRS adoption, that is, on "yes" or "not" binary variables, and following other studies (HODGDON et al., 2008; GLAUM et al., 2013), we use a de facto compliance index per firm, to evaluate significant associations between firms' levels of compliance with IFRS and analysts' earnings forecast errors.

We find that, in the Brazilian context, the higher firms' compliance with IFRS disclosure requirements is, the smaller is the analysts' earnings forecast errors, thus confirming our hypothesis. These findings reinforce the idea that, for improving analysts' forecast accuracy, compliance with IFRS is at least as important as the mere formal IFRS adoption.

This study is unique in its approach to the effective IFRS disclosure compliance impacts on analysts' earnings forecasts in the Brazilian securities market. Although its findings stay in line with part of prior international literature, it can also be an interesting contribution to international research, as it examines the disclosure issue 
in an accounting environment combining several factors of a Latin-American emerging economy that can jeopardize transparency (code-law tradition, less efficient financial market and insufficient enforcement). Indeed, such limitations can make our study on a "less developed capital market" advantageous over researches on efficient markets, in which, as pointed out by Verrecchia (2001, p. 173-174), only incremental disclosure improvements are observable and not easy to detect. These findings can also have practical implications for regulators and standard setters, given the current worldwide discussion on the IFRS disclosure policies (IFRS, 2013).

\section{PRIOR RESEARCH AND HYPOTHESIS DEVELOPMENT}

\subsection{Theory of Disclosure}

Akerlof (1970) develop a theory based on the used cars market, according to which lacking sellers' information disclosure about bad used cars ("lemons") causes buyers to mistrust, thus to distance also from good used cars ("plums" or "cherries"); this generates an adverse selection that contaminates all the market. Since then, this theory is seen as a fundamental interpretation of markets failures. similarly, resale and corporate securities markets suffer from the problem of asymmetric information, as some market participants are better informed than others about the value of the good to be negotiated. Based on this analysis, the theory suggests that only a part of the potential gains of a negotiation is performed. Therefore, the expected break-even point depends on the quality of information concerning the party and the counterparty of the business, that is, on the degree of information asymmetry between the two sides of the market.

Moreover, information asymmetry can cause agency conflicts. An agency problem arises because minority investors do not normally have the intention to play an active role in the company's administration and delegate this responsibility to the majority investor (or manager). Consequently, these investors put their resources at risk when they invest in a company, whose majority has incentive to take decisions that may expropriate the minority shareholders. For example, the majority can use minority's invested resources to obtain gratuities, pay excessive compensation or make investments which are harmful to minority stakeholders' interests (JENSEN and MECKLING, 1976).

Such conflicts, before or after investment, can be avoided by voluntary firms' disclosure, which is always based on cost / benefits considerations for the firms, thus discouraging disclosure of bad news. Therefore, regulators have the function to establish standards for mandatory disclosure, ensuring that relevant information, even if unfavorable to the reporting firm, will also be available (DYE, 1990, 2001; HEALY and PALEPU, 2001).

In this sense, mandatory accounting disclosure is a key to market efficiency, making relevant information available to investors and enabling effective allocation of resources. La Porta, Lopez-de-Silanes, Shleifer, and Vishny (2000) note that when investors finance companies, they usually obtain rights or powers that are guaranteed by rules or laws. These rights include the disclosure and accounting norms that provide the investors with the necessary information for exercising other rights.

80 Revista Contabilidade Vista \& Revista, ISSN 0103-734X, Universidade Federal de Minas Gerais, Belo Horizonte, v. 29, n. 1, p.77-100, jan/abr. 2018 
Several studies evaluate if the implementation of IFRS improves accounting quality, with different results. Some find a positive relation of the IFRS adoption with accounting quality (DASKE and GEBHARDT, 2006; BARTH, LANDSMAN, and LANG, 2008; JIAO, KONING, MERTENS and ROOSEMBOOM, 2011); other studies do not find evidence of accounting quality improvement after IFRS implementation (VAN TENDELOO and VANSTRAELEN 2005; GLAUM et al., 2013; GATSIOS, 2013); and other find that incentives predominate in determining accounting quality improvement by IFRS adoption (DASKE et al., 2013; CHRISTENSEN, LEE, WALKER, and ZENG, 2015).

\subsection{Factors that Influence Analysts' Earnings Forecast Errors}

The earnings per share index (EPS) demonstrates the portion of a company's profit allocated to each outstanding share in a given period.

This index forecast is a relevant factor for determining shares' prices traded on the market, as a signaling value for capital allocation in the economy. It is expected that the market reflects shares prices with assertiveness to provide efficient resources allocation, that is, a market in which companies can make investment decisions in production, and investors can choose among the assets which better represent the companies' activities, under the assumption that the assets' prices reflect all available information at any time. To evaluate the components that influence analysts' earnings forecast errors, we assume the premise that the markets have the weak form efficiency, absorbing past information in its prediction at least (FAMA, 1970).

Research about analysts forecasts can be divided into two categories: the first one focuses the analysts' consensus, measured by the mean or median of analysts' earnings forecast recommendations for a company in a given period, and it is known as the street consensus; the second one is represented by the forecasts and/or recommendations of individual analysts (MARTINEZ, 2004).

As Martinez (2004) points out, the consensus analysis is based on that the best representation of the market expectations can be obtained by a central tendency distribution of the analysts' projections and/or recommendations. In this perspective, the present study is based on the analysts' consensus in order to eliminate individual biases and obtain the mean of market expectations.

As mentioned, studies about factors that influence analysts' earnings forecast errors are numerous in the international literature (LANG and LUNDHOLM, 1996; HUSSAIN, 1997; BARRON et al., 1999; HOPE, 2003a, 2003b; VANSTRAELEN, ZARZESKI and ROBB, 2003; HODGDON et al., 2008; GLAUM et al., 2013) and few on the Brazilian context (DA SILVA, 1998; MARTINEZ, 2004; PESSOTI, 2012; GATSIOS, 2013).

The factors that influence analysts' forecasts are summarized in Table 1. 
Table 1 - Factors that Influence Analysts' Earnings Forecast Errors

\begin{tabular}{|c|c|c|c|}
\hline Item & Description & Authors & $\begin{array}{l}\text { Expected } \\
\text { Signal }\end{array}$ \\
\hline SIZE & $\begin{array}{l}\text { Size of the firm, measured } \\
\text { by the value of total assets } \\
\text { in BRL (real), at the end of } \\
\text { period t for the firm } j\end{array}$ & $\begin{array}{l}\text { Lang and Lundholm, 1996; Barron } \\
\text { et al., 1999; Hope, 2003a, 2003b; } \\
\text { Vanstraelen et al., 2003; Hodgdon } \\
\text { et al., } 2008 \text { and Glaum et al., } 2013\end{array}$ & $(-)$ \\
\hline SIGNAL & $\begin{array}{l}\text { If the index earnings per } \\
\text { share (EPS) was negative in } \\
\text { the year }(t+1) \text { and positive } \\
\text { in year } t \text { considers } 1 \text {, and } 0 \text {, } \\
\text { otherwise }\end{array}$ & $\begin{array}{l}\text { Hope, 2003a, 2003b; Lang and } \\
\text { Lundholm, 1996; Hodgdon et al., } \\
2008 \text { and Glaum et al., } 2013\end{array}$ & $(+)$ \\
\hline CHANGE & $\begin{array}{l}\text { Percentage of alteration in } \\
\text { the earnings per share } \\
\text { (EPS) index of year }(t-1) \text { to } \\
\text { year } t\end{array}$ & $\begin{array}{l}\text { Hussain, 1997; Barron et al., 1999; } \\
\text { Hope, 2003b; Hodgdon et al., } 2008 \\
\text { and Glaum et al., } 2013\end{array}$ & $(+)$ \\
\hline SDRET & $\begin{array}{l}\text { Share daily returns } \\
\text { standard deviation of the } \\
\text { firm } j \text { in period } t\end{array}$ & $\begin{array}{l}\text { Lang and Lundholm, 1996; } \\
\text { Martinez, 2004; Glaum et al., } 20113\end{array}$ & $(+)$ \\
\hline $\mathrm{ROA}$ & $\begin{array}{l}\text { Return on assets at the end } \\
\text { of period } t \text { for the firm } j\end{array}$ & Glaum et al., 2013 & $(-)$ \\
\hline LEVERAGE & $\begin{array}{l}\text { Total Liabilities/Total Assets } \\
* 100 \text { (in period t to the firm } \\
\text { j) }\end{array}$ & $\begin{array}{l}\text { Hope, 2003a, 2003b; Glaum et al., } \\
2013\end{array}$ & $(+)$ \\
\hline LISTED IN USES & $\begin{array}{l}\text { Listed in the US Stock } \\
\text { Exchange in the period } t\end{array}$ & $\begin{array}{l}\text { Hope, 2003a, 2003b; Vanstraelen } \\
\text { et al., 2003; Hodgdon et al., } 2008 \\
\text { and Glaum et al., } 2013\end{array}$ & $(-)$ \\
\hline THE SECTOR & $\begin{array}{l}\text { Segregation of firms by } \\
\text { sectors }\end{array}$ & $\begin{array}{l}\text { Hussain, 1997; Hope, 2003a, 2003b; } \\
\text { Vanstraelen et al., 2003; Hodgdon } \\
\text { et al., } 2008 \text { and Glaum et al., } 2013\end{array}$ & $(+/-)$ \\
\hline $\begin{array}{l}\text { TIME } \\
\text { PROJECTION }\end{array}$ & $\begin{array}{l}\text { Number of days between } \\
\text { the projection and the } \\
\text { dissemination of the } \\
\text { outcome of the trade } \\
\text { name j for the period } t\end{array}$ & $\begin{array}{l}\text { Martinez, 2004; Hodgdon et al., } \\
2008\end{array}$ & $(+)$ \\
\hline $\begin{array}{l}\text { TREASURY } \\
\text { SHARES }\end{array}$ & $\begin{array}{l}\text { Shares held in treasury on } \\
\text { the firm } \mathrm{j} \text { in period } t\end{array}$ & Glaum et al., 2013 & $(-)$ \\
\hline $\begin{array}{l}\text { QUANTITY OF } \\
\text { ANALYSTS }\end{array}$ & $\begin{array}{l}\text { Number of analysts that } \\
\text { accompany the business } \\
\text { name }\end{array}$ & $\begin{array}{l}\text { Lang and Lundholm, 1996; Barron } \\
\text { et al., 1999; Martinez, 2004; Hope, } \\
\text { 2003a, 2003b; Hodgdon et al., } \\
2008 \text { and Glaum et al., } 2013\end{array}$ & $(-)$ \\
\hline $\begin{array}{l}\text { REVENUES } \\
\text { ABROAD }\end{array}$ & $\begin{array}{l}\text { Sales abroad divided by } \\
\text { the total number of sales of } \\
\text { year t to the firm } j\end{array}$ & $\begin{array}{l}\text { Hodgdon et al., } 2008 \text { and Glaum } \\
\text { et al., } 2013\end{array}$ & $(+)$ \\
\hline $\begin{array}{l}\text { OPA (Public } \\
\text { Offering of } \\
\text { Shares) }\end{array}$ & $\begin{array}{l}\text { If there is Public Offering of } \\
\text { Shares in year } t+1 \text {, it is } \\
\text { considered } 1 \text { and } 0 \text {, } \\
\text { otherwise }\end{array}$ & Glaum et al., 2013 & $(+)$ \\
\hline
\end{tabular}

Source: Prepared by the authors. 


\subsection{Previous Studies about Influence of Disclosure on Analysts' Earnings Forecast Accuracy}

Some international studies address the correlation between analysts' earnings forecast accuracy and disclosure levels (LANG and LUNDHOLM, 1996; ASHBAUGH and PINGUS, 2001; HOPE 2003a, 2003b; CUIJEPERS and BUIJINK, 2005). Earlier studies analyze the relation between disclosure levels and analysts' forecast accuracy, and recent studies address this issue in the context of international standards adoption (US GAAP or IFRS).

Among earlier studies, Lang and Lundholm (1996) examine the relation between firms' disclosure practices and properties of analysts' forecasts, and find that firms with more informative disclosure policies have a larger analysts following, more accurate earnings forecasts, less dispersion among individual analysts' forecasts and less volatility in forecast revisions. In a similar study, Hope (2003b) controls the disclosure effects by firm and country of origin and identifies that the disclosure level is significantly and negatively related with the analysts' earnings forecast errors; Hope (2003a) finds evidence of the importance of a strong enforcement on improving analysts' forecast accuracy.

There is no consensus about analysts' errors reduction after international standards adoption.

On the one hand, Ashbaugh and Pingus (2001), studying a sample of companies from various countries except the United States, and using indexes of differences in countries' accounting disclosure and measurement policies relative to IAS, verify that the analysts' earnings forecasts accuracy has a sensitive improvement after the IAS adoption. Also, Hodgdon et al. (2008), analyzing 89 firms that claimed to adopt IFRS in the years 1999 and 2000, most of them European, found a negative relation between an index of compliance with IFRS required disclosure and analysts' forecast errors.

On the other hand, Daske (2005) (apud GLAUM et al., 2013), and Cuijepers and Buijink (2005), by examining, respectively, a sample of German or European companies for the impact of voluntary US GAAP or IFRS adoption on analysts' forecasts, find that analysts' forecast errors are greater for companies that have adopted an international standard (US GAAP or IFRS) than for companies that applied the traditional local GAAP.

Glaum et al. (2013) find that the introduction of international accounting standards by German companies has been associated with a significant improvement in forecast accuracy, but the disclosure effect, while significant, explains only a small portion of the overall improvement in forecast accuracy.

Meek and Thomas (2004) and Hodgdon et al. (2008) consider that the limited evidence existing in this area of research makes it necessary to examine analysts' earnings forecast errors considering IFRS compliance at the company level. Indeed, Street, Gray and Bryant (1999) and Street and Gray (2002) find that compliance with IFRS disclosure requirements is in general very heterogeneous. This is confirmed for Brazil by Santos et al. (2014) and Mapuranga et al. (2011), who find also low disclosure compliance levels in Brazil. 
We do not find studies in the Brazilian context, that examine the relationship between compliance with IFRS disclosure requirements and analysts forecast accuracy. As mentioned, the only two studies evaluating the influence of the IFRS adoption on the analysts' forecasts accuracy (PESSOTI, 2012; GATSIOS, 2013) have the same limitation of using binary variables for identifying when companies began to report in IFRS, and by not controlling for the firm level of compliance with IFRS disclosure requirements. These studies obtain different results: Pessotti (2012) finds that the accuracy of analysts is higher for earnings forecasts based on IFRS or US GAAP, but also that there is a decline in analysts' accuracy in the first two years of the international standard adoption; in contrast, Gatsios (2013) finds that the dispersion of the analysts' estimates has increased in the partial IFRS adoption period, indicating that the mandatory adoption of IFRS in Brazil still not contributed to the reduction of analysts' forecasting errors.

Unlike these studies in the Brazilian context, our research does not assess simply the correlation of the IFRS adoption year with the change in the analysts' forecasts accuracy. Following Hodgdon et al. (2008), we examine the relationship between firms' levels of compliance with IFRS disclosure requirements and analysts' earnings forecast errors, in order to control for firms that, while adopting mandatory IFRS, do not adequately comply with the IFRS disclosure requirements.

\subsection{Hypothesis}

From the previous literature, although without consensus, it is possible to expect that the firm' compliance level with IFRS disclosure requirements is negatively associated with the analysts' earnings forecast errors. So, we test the following hypothesis:

The higher the Brazilian firms' compliance with IFRS disclosure requirements is, the smaller is the analysts' earnings forecast errors.

This hypothesis seeks to isolate the idiosyncratic factors of the firm that occasionally may impact analysts' forecasts. In addition, the effects that do not vary in time can be isolated, as the analyst familiarity with the company, and the business characteristics of the firm, that are considered as "fixed effect" for the forecasts. In this sense, to control the effects that do not vary in time, a two years panel data (2010 and 2012) with fixed effects is structured. 


\section{METHODOLOGY}

\subsection{Selecting Data - Forecasted and Actual EPS}

Analysts' forecasted earnings' data are obtained from I/B/E/S Earnings Consensus Information, provided by Thomson One Investment Banking platform, and actual earnings reported by the firms are obtained from Economática Pro $\AA$.

By selecting our sample, we first take all the (366) companies listed on the BM\&FBOVESPA. From this total it is possible to select 123 companies, for which both forecasted and actual earnings data are available for 31 December 2010 and 31 December 2012.

The I/B/E/S contains forecasts and recommendations of analysts to several companies in the world, including Brazilian companies. The database of this system has three main sections: a) Detail History, containing the individual estimates of analysts per company over time; b) Summary History, which contains the consensus of the estimates of all analysts for a firm within a given period and; $c$ ) Recommendations, which lists the analysts' recommendations regarding purchase or sale.

In this study, we use the database "Summary History", which offers the average estimate by company, metrics and period (estimate of consensus).

In order to ensure results robustness and to minimize autocorrelation problems between forecasts errors from different consensus over a year (Martinez, 2004), our analysis uses only forecasts included in the December Consensus of each year.

\subsection{Dependent Variable: Forecasting Error}

The dependent variable in this study is the analysts' earnings forecast error for the 123 companies listed on the BM\&FBOVESPA for which both forecasted and actual earnings per share (EPS) are available.

To estimate the forecast error in fiscal year $y+t$, where $t$ is the year of the financial statements report, the variable error ${ }_{i, t+1}$ is defined as the value of the difference between the earnings per share (EPS) of the company $i$ in fiscal year $y_{t+1}$ and the average of forecast consensus of earnings per share for the company $i$ to fiscal year $y_{t+1}$, divided by earnings per share of company $i$ in fiscal year $y_{t+1}$, as described in equation (1):

$$
\text { Error }_{i, t+1}=\frac{\text { EPS }_{i, t+1}-\text { EPS forecast }_{i, t+1}}{\text { EPS }_{i, t+1}}
$$

The annual financial statements are published within a specific period (up to 3 months) after the end of the fiscal year t. This result is not known when forecasts for year $t+1$ are published by market analysts. Therefore, in order to calculate the analysts forecast error, the average available in the database I/B/E/S Earnings Consensus Information for the end of the fiscal year $t+1$ is adopted.

Previous studies adopt the same methodology (Hope 2003a, 2003b; Glaum et al. 2013; Barron et al. 1999; Hodgdon et al. 2008). The denominator used in this Revista Contabilidade Vista \& Revista, ISSN 0103-734X, Universidade Federal de Minas Gerais, $\quad 85$ Belo Horizonte, v. 29, n. 1, p. 77-100, jan/abr. 2018 
study $\left(\right.$ EPS $\left._{\mathrm{i}, \mathrm{t}+1}\right)$ is employed by Barron et al. (1999) and Hodgdon et al. (2008), instead of using the share market value, as per Lang \& Lundholm (1996) and Glaum et al. (2013). Indeed, when earnings per share is adopted in the denominator, the value obtained is a percentage, which can be more intuitively assessed.

\subsection{Independent Variable: the Disclosure Index}

For measuring the firm' level of compliance with IFRS disclosure requirements, we take the Notes to Financial Statements for the fiscal years of 2010, the full IFRS adoption year in Brazil, and of 2012, for our sample of 123 companies.

Following the methodology used by Santos et al. (2014), the disclosure index is determined for each standard issued by the Brazilian accounting standard setting committee (Comitê de Pronunciamentos Contábeis - CPC), which is fully converged with IFRS (IFRS, 2015) and is rendered mandatory for the Brazilian listed companies by the Brazilian Securities and Exchange Commission (CVM, 2009).

We select 23 standards according to the importance of their disclosure contents, including 20 pronouncements (CPCs), 1 technical orientation (OCPC) and 2 interpretations (ICPC). To facilitate data collection and analysis, we decoupled some standards and combined others, thus obtaining 25 thematic standards, lato sensu (as the term standard is hereafter used).

Then, we structure an encompassing checklist with all standards' paragraphs that contain disclosure requirements, thus obtaining 172 paragraphs. Paragraphs specifying more than one disclosure requirement are subdivided into items, which totals 501 required disclosure items, as shown in Table 2.

Table 2 - Standards Considered for the Disclosure Compliance Index and Reference to IAS/IFRSs

\begin{tabular}{|c|c|c|c|c|}
\hline $\mathbf{N}$ & The theme of the standard & $\begin{array}{l}\text { CPC and } \\
\text { IAS/IFRS }\end{array}$ & $\begin{array}{l}\text { Standard' } \\
\text { paragraphs with } \\
\text { disclosure } \\
\text { requirements }\end{array}$ & $\begin{array}{l}\text { Number of } \\
\text { required } \\
\text { items }\end{array}$ \\
\hline 1 & Impairment of Assets & CPC 01 (IAS 36) & 126 and 129 to 133 & 27 \\
\hline 2 & Intangible Assets & CPC 04 (IAS 38) & $118,121,122$ and 126 & 32 \\
\hline 3 & Related Party Disclosures & CPC 05 (IAS 24) & $13,17,18,19$ and 26 & 56 \\
\hline 4 & $\begin{array}{l}\text { Financial Lease for the } \\
\text { Lessee }\end{array}$ & CPC 06 (IAS 17) & 31 & 12 \\
\hline 5 & $\begin{array}{l}\text { Operating Lease for the } \\
\text { Lessee }\end{array}$ & CPC 06 (IAS 17) & 35 & 11 \\
\hline 6 & $\begin{array}{l}\text { Transaction Costs and } \\
\text { Premium on the Issuance } \\
\text { of Securities }\end{array}$ & $\begin{array}{l}\text { CPC } 08 \text { (parts } \\
\text { of IAS } 32 \text { and } \\
39 \text { ) }\end{array}$ & 20 & 5 \\
\hline 7 & Share-based Payment & CPC 10 (IFRS 2) & 45 and 48 to 51 & 39 \\
\hline 8 & Business Combinations & CPC 15 (IFRS 3) & (B64 and B67 & 81 \\
\hline 9 & Inventories & CPC 16 (IAS 2) & 36 & 10 \\
\hline 10 & Investments in Associates & CPC 18 (IAS 28) & 37 and 40 & 12 \\
\hline 11 & $\begin{array}{l}\text { Investment in Joint } \\
\text { Ventures }\end{array}$ & CPC 19 (IAS 31) & 54 to 57 & 12 \\
\hline 12 & Borrowing Costs & CPC 20 (IAS 23) & 26 & 2 \\
\hline
\end{tabular}




\begin{tabular}{|c|c|c|c|c|}
\hline $\mathbf{N}$ & The theme of the standard & $\begin{array}{l}\text { CPC and } \\
\text { IAS/IFRS }\end{array}$ & $\begin{array}{c}\text { Standard' } \\
\text { paragraphs with } \\
\text { disclosure } \\
\text { requirements }\end{array}$ & $\begin{array}{l}\text { Number of } \\
\text { required } \\
\text { items }\end{array}$ \\
\hline 13 & Operating Segments & CPC 22 (IFRS 8) & $\begin{array}{c}21 \text { to } 24,27 \text { and } 31 \text { to } \\
34\end{array}$ & 34 \\
\hline 14 & Accounting Policies & CPC 23 (IAS 8) & 28 and 29 & 7 \\
\hline 15 & $\begin{array}{l}\text { Changes in Accounting } \\
\text { Estimates }\end{array}$ & CPC 23 (IAS 8) & 39 & 2 \\
\hline 16 & Errors & CPC 23 (IAS 8) & 49 & 6 \\
\hline 17 & $\begin{array}{l}\text { Events After the Reporting } \\
\text { Period }\end{array}$ & CPC 24 (IAS 10) & 17 and 21 & 5 \\
\hline 18 & $\begin{array}{l}\text { Provisions, Contingent } \\
\text { Liabilities and Contingent } \\
\text { Assets }\end{array}$ & CPC 25 (IAS 37) & 84 to 86,89 and 92 & 21 \\
\hline 19 & $\begin{array}{l}\text { Property, Plant and } \\
\text { Equipment }\end{array}$ & $\begin{array}{l}\text { CPC } 27 \text { (IAS 16) } \\
\text { and ICPC } 10 \\
\text { (IFRS 1) }\end{array}$ & $\begin{array}{l}73 \text { to } 76 \\
41 \text { and } 42\end{array}$ & 34 \\
\hline 20 & Investment Property & CPC 28 (IAS 40) & $75,76,78$ and 79 & 34 \\
\hline 21 & Revenue & CPC 30 (IAS 18) & 35 & 5 \\
\hline 22 & $\begin{array}{l}\text { Consolidated Financial } \\
\text { Statements }\end{array}$ & CPC 36 (IAS 27) & 41 & 10 \\
\hline 23 & Earnings per Share & CPC 41 (IAS 33) & 70 and 79 & 12 \\
\hline 24 & $\begin{array}{l}\text { Accounting for the } \\
\text { Payment of Proposed } \\
\text { Dividends }\end{array}$ & ICPC 08 (NA) & 14 & 1 \\
\hline 25 & Financial Instruments & OCPC 03 (NA) & 79 & 31 \\
\hline
\end{tabular}

Source: Santos et al. (2014) - adapted by the authors.

The research codes each IFRS-required disclosure item as disclosed (1), not disclosed (0), or not applicable (NA).

The same trained researcher verifies the same items for the 123 firms - in order to minimize subjective bias.

Criteria to Verify the Applicability of a Standard to a Firm. The applicability of a standard to a firm is sometimes directly verifiable from a Balance Sheet or Income Statement account; in other cases, the information on applicability can be found only in Notes. For example, the applicability of the Intangible Assets standard (CPC 04 / IAS 38) to a firm can be verified by existence of a non-zero balance in the account Intangible Assets in the Balance Sheet; but for Operating Lease for the Lessee (CPC 6 / IAS 17), there is no specific account in the Balance Sheet or Income Statement; thus, the applicability of this standard to a firm is verifiable only if it was specified in Notes.

However, as reported by Santos et al. (2014), numerous Brazilian firms did not mention in their Notes some standards whose applicability could only be verified in Notes; but, several other companies explicitly reported in Notes that a specific standard is not applicable to them. On the one side, we cannot assume that one standard is not applicable to a firm simply because nothing is mentioned about this standard in the Notes. On the other side, there is no rule determining that a firm has to explicitly indicate in Notes that a standard is not applicable to it. Therefore, being this a matter of judgment, and following Santos et al. (2014), we establish for 
these cases two alternative criteria to measure the compliance with IFRS required disclosure:

Criterion 1 (strict). A standard is considered applicable if there is no information in Notes about its non-applicability, and all its required disclosure items are coded as not disclosed (0). This criterion penalizes the firm which does not express clearly the non-applicability of a standard to it, because this behavior induces the users of financial statements to believe that the firm does not have that kind of transaction. On the other hand, when this criterion is adopted, it assumes the risk of penalizing the firms that omit only the information that does not apply to them.

Criterion 2 (tolerant): A standard is considered not applicable (NA), if there is no information in Notes about its non-applicability; therefore, its disclosure required items are excluded from the disclosure index. This criterion does not penalize a firm which, correctly, does not disclose information that does not apply to it. On the other hand, this criterion assumes the risk of considering that all lacking information is due to non-applicability.

The criteria used to verify the standard applicability to a firm are demonstrated on Table 3.

Table 3 - Criteria for Establishing the Applicability of a Standard to a Firm

\begin{tabular}{|c|c|}
\hline $\begin{array}{l}\text { Standards whose applicability could be } \\
\text { checked in the Balance Sheet or Income } \\
\text { Statement }\end{array}$ & $\begin{array}{l}\text { Standards whose applicability could only } \\
\text { be checked in the Notes }\end{array}$ \\
\hline Intangible Assets (CPC 04 / IAS 38) & Impairment of Assets (CPC 01 / IAS 36) \\
\hline Related Party Disclosures (CPC 05 / IAS 24) & $\begin{array}{l}\text { Operating Lease for the Lessee (CPC } 06 \text { / } \\
\text { IAS 17) } \\
\text { Transaction Costs and Premium on the }\end{array}$ \\
\hline $\begin{array}{l}\text { Financial Lease for the Lessee (CPC } 06 \text { / IAS } \\
\text { 17) }\end{array}$ & $\begin{array}{l}\text { Transaction Costs and Premium on the } \\
\text { Issuance of Securities (CPC } 08 \text { / parts of } \\
\text { IAS } 32 \text { and 39) }\end{array}$ \\
\hline Inve & Payment (CPC 10 / IFRS 2) \\
\hline Investments in & CPC 15 / IFRS 3) \\
\hline Investment in Joint Venture & Borrowing Costs $(\mathrm{C}$ \\
\hline $\begin{array}{l}\text { Property, Plant and Equipment (CPC } 27 \text { / IAS } \\
\text { 16; ICPC } 10 \text { / IFRS 1) }\end{array}$ & Operating Segments (CPC 22 / IFRS 8) \\
\hline Investment Property (CPC 28 / IAS 40) & \\
\hline Revenue (CPC 30 / IAS 18) & $\begin{array}{l}\text { s in Accounting Estimates (CPC } \\
\text { 3) }\end{array}$ \\
\hline Consolidated Statements (CPC 36 / IAS 27) & Errors (CPC 2 \\
\hline Earnings per Share (CPC 41 / IAS 33) & $\begin{array}{l}\text { Events After the Reporting Period (CPC } 24 \\
\text { / IAS 10) }\end{array}$ \\
\hline $\begin{array}{l}\text { Accounting for the Payment of Proposed } \\
\text { Dividends (ICPC } 08 \text { / NA) }\end{array}$ & $\begin{array}{l}\text { Provisions, Contingent Liabilities and } \\
\text { Contingent Assets (CPC } 25 \text { / IAS 37) } \\
\text { Financial Instruments (OCPC } 03 \text { / NA) }\end{array}$ \\
\hline
\end{tabular}

Source: Santos et al. (2014) - adapted by the authors.

Calculating the Overall Disclosure Compliance Index. Following other studies (Street \& Gray, 2002; Tsalavoutas, Evans, \& Smith, 2010; Santos et al., 2014), we use two approaches to calculate the overall disclosure compliance 
index (considering all standards): (1) accumulating by disclosure item and (2) accumulating by standard.

(1) Accumulation by Disclosure Item (DI) (known as dichotomous approach): consists in attributing equal weight to all items of disclosure, regardless of the number of items required by each standard. This ends up giving a greater weight to the standards having a higher number of disclosure requirements. Thus, the firm' disclosure compliance index is calculated by the ratio between the total items disclosed and the total items applicable to each firm (Cooke, 1992; Street \& Gray, 2002; Hodgdon et al., 2008; Tsalavoutas et al., 2010; Santos et al., 2014), as demonstrated in equation (2):

$$
\text { DIx }=\frac{\mathrm{TTx}}{\mathrm{ATx}}=\frac{\sum_{\mathrm{y}}^{\mathrm{m}} \mathrm{Tx}, \mathrm{y}}{\sum_{\mathrm{y}}^{\mathrm{m}} \mathrm{Ax}, \mathrm{y}}
$$

Where: DIx is the disclosure compliance index of firm $x$ according to the dichotomous approach $(0 \leq D / x \leq 1)$; TTx is the total number of items disclosed by the firm $x$ for all $m$ standards applicable to the firm $x$; and ATx is the number of items applicable to the firm $x$ for all $m$ standards applicable to the firm $x$. (Tx,y is explained bellow).

(2) Accumulation by Standard (DS) (known as partial compliance unweighted approach): consists in assigning equal weight to each standard. The overall disclosure index is obtained by the ratio between the sum of the disclosure compliance scores of each standard and the sum of the number of standards applicable to each firm (Street \& Gray, 2002; Tsalavoutas et al., 2010; Santos et al., 2014). In this approach, the calculation of the firms' disclosure index is made in two steps:

(i) Calculation of the disclosure index by standard. As demonstrated in equation (3):

$$
\mathrm{Dx}, \mathrm{y}=\frac{\mathrm{Tx}, \mathrm{y}}{\mathrm{Ax}, \mathrm{y}}
$$

Where: $\mathrm{Dx}, \mathrm{y}$ is the compliance disclosure score for the standard $\mathrm{y}$ of the firm $\mathrm{x}(0 \leq$ $\left.D_{x, y} \leq 1\right) ; T x, y$ is the total number of items disclosed by firm $x$ for the standard $y$; and $A x, y$ is the number of items applicable to firm $x$ for the standard $y$.

(ii) Calculation of the overall disclosure index. Determined by the ratio between the sum of each firm's disclosure scores by standard and the sum of the number of standards applicable to each firm, as demonstrated through equation (4):

$$
\mathrm{DSx}=\frac{\sum_{\mathrm{y}=1}^{\mathrm{m}} \mathrm{Dx}, \mathrm{y}}{\mathrm{m}}
$$

Where: DSx is the compliance disclosure index of firm $x$ according to the partial compliance unweighted approach $(0 \leq \mathrm{DS} x \leq 1)$; $\mathrm{Dx}, \mathrm{y}$ is the compliance disclosure score of the standard $y$ for the firm $x$; and $m$ is the number of standards applicable to the firm $x$. 


\subsection{Control Variables - Other Factors that Influence Analysts' Forecasts}

Following the methodology adopted by previous studies (LANG and LUNDHOLM, 1996; HUSSAIN, 1997; BARRON, et al. 1999; HOPE, 2003a, 2003b; VANSTRAELEN et al., 2003; MARTINEZ, 2004; HODGDON et al., 2008; GLAUM et al., 2013), the selected factors that have an influence in the analysts' earnings forecast errors are shown in Table 4.

These studies generally segregate firms by industry; meanwhile, as the sample selected for this research contains only 123 companies, the segregation by industry becomes dispensable. Besides, the control variables used in other studies, but not in our study are:

- The number of days between the forecast and the disclosure of the firm $\mathrm{j}$ for this period $t$ (AGE), because all the forecasts were obtained in the month of December;

- The indicator of the shares held by the firm (CLOSE); the indicator of the offer of shares in the period (SEO - seasoned equity offerings), which aims to capture the capital structures concentrated; and the international operations of the company (INT), because these factors were not observed for the sample;

- The number of analysts which follow the firm (ANALYST), because this factor is used to assess the accuracy of individual analysts.

Table 4 - Control Variables

\begin{tabular}{|c|c|c|}
\hline $\begin{array}{l}\text { Control } \\
\text { Variable }\end{array}$ & Description & Source \\
\hline SIZE & $\begin{array}{l}\text { Size of the firm, measured by the value of total assets in BRL, } \\
\text { at the end of period t for the firm } j\end{array}$ & Economática \\
\hline SIGN & $\begin{array}{l}\text { If the earnings per share (EPS) index was negative in the year } \\
(t+1) \text { and positive in year } t \text {, it is considered } 1 \text { and } 0 \text {, otherwise }\end{array}$ & Economática \\
\hline CHANGE & $\begin{array}{l}\text { Percentage of alteration in the earnings per share (EPS) index } \\
\text { on year }(t-1) \text { to year } t\end{array}$ & Economática \\
\hline SDRET & Share daily returns standard deviation of the firm $\mathrm{j}$ in period $t$ & Economática \\
\hline $\mathrm{ROA}$ & Return on assets at the end of period $t$ for the firm $j$ & Economática \\
\hline LEVERAGE & Total Liabilities/Total Assets * 100 (in period $t$ for the firm j) & Economática \\
\hline US_LIST & Listed on the US Stock Exchange in period $t$ & Economática \\
\hline YEAR & If the year is 2012 , it is considered 1 and 0 , otherwise & Manual \\
\hline
\end{tabular}

Source: Prepared by the authors.

Finally, we analyze per year, in order to capture any differences in examination of these firms between the years.

\subsection{Regression}

We define a model log-log for OLS (Ordinary Least Squares) with the aim of capturing the elasticities between the dependent variable and the explanatory variables; in other words, the size of the impact that the change in each explanatory variable exercises on the analysts forecasting errors.

The relationship between all the explanatory variables and the dependent variable is verified individually, by assessing the scatter charts and, from this 
analysis, we find that the format that fits better is when it is used the natural log (LN) for all variables. Additionally, we include the quadratic format of the natural log for the explanatory variables Size, Change, Leverage and Share Daily Returns Standard Deviation, in order to capture the marginal impact of increase or decrease in the logistic regression.

This functional specification is adhering to the model used by Hodgdon et al. (2008), except for the fact that, in our study, we verify a strong evidence of a linear relationship between the disclosure variables and analysts' forecasting errors. Thus, the regression model used in our study is defined in equation (5):

$$
\begin{aligned}
& L N E R R O_{i, t+1}=\beta_{0}+\beta_{1} L N S I Z E+\beta_{2} L N S I Z E^{2}+\beta_{3} S I G N+\beta_{4} L N C H A N G E+ \\
& \beta_{5} L N C H A N G E^{2}+\beta_{6} L N L E V E R A G E+\beta_{7} L N L E V E R A G E^{2}+\beta_{8} L N S D R E T+ \\
& \beta_{9} L N S D R E T^{2}+\beta_{10} Y E A R+\beta_{11} L N D I S C_{-} n+\varepsilon
\end{aligned}
$$

Where:

LNERRO = natural log of the analysts' earnings forecast errors absolute value (Summary History), for the firm j, in period t; LNSIZE = natural log of the size of the firm, measured by the total assets value of the firm in BRL, at the end of period $t$ for the firm j; SIGN = if the earnings per share (EPS) index is negative in the year $(\dagger+1)$ and positive in year $t$, it was considered 1 and 0 , otherwise; LNCHANGE = natural log of the alteration percentage of the absolute value of the earnings per share (EPS) index of year ( $t-1)$ to year $t$; $L N L E V E R A G E=$ natural log of the liabilities/Total Assets * 100 (in period t to the firm j); LNSDRET = natural log of the share daily returns standard deviation of the firm $\mathrm{j}$ in period $\mathrm{t}$; YEAR $=$ if the year is 2012 , it is considered 1 and 0 , otherwise; LNDISC_n = natural log of the disclosure index by firm $\mathrm{j}$ in period $t$, using four metrics; $\varepsilon=$ error of the model.

\section{RESULTS}

\subsection{The Forecast Errors}

Our results are in line with Martinez (2004), who performs a detailed analysis of the distribution of the analysts' forecasting errors, from January 1995 until June 2003. This analysis reveals that the ratio between the forecasting errors (positive or negative) between symmetrical distribution intervals increases systematically as it approaches the central distribution points. These data demonstrate that the positive forecast errors (pessimistic ex-post) dominate over the negative forecast errors (optimistic ex-post). Therefore, it is possible to assert that the analysts have an optimistic prediction bias, that is, their forecasts are, most of the times, better than the results actually achieved.

\subsection{The Control Variables}

Table 5 presents the descriptive statistics for selected control variables, in order to isolate the effects which might influence the analysts' earnings forecast errors. 
Table 5 - Descriptive Statistics for Control Variables

\begin{tabular}{ccccccccc}
\hline & \multicolumn{4}{c}{$\mathbf{2 0 1 0}$} & \multicolumn{5}{c}{$\mathbf{2 0 1 2}$} \\
Variable & Mean & S.D. & Min & Max & Mean & S.D. & Min & Max \\
\hline LN (size) & 6.61 & 0.65 & 4.38 & 8.72 & 6.78 & 0.61 & 5.53 & 8.83 \\
Signal & 0.11 & 0.31 & 0.00 & 1.00 & 0.03 & 0.18 & 0.00 & 1.00 \\
ROA & 0.07 & 0.07 & -0.06 & 0.49 & 0.04 & 0.08 & -0.34 & 0.27 \\
Leverage & 25,26 & 16.48 & 0.00 & 64.70 & 30.43 & 17.33 & 0.00 & 61.17 \\
Change & 0.35 & 2.49 & -7.20 & 23.46 & 0.29 & 3,12 & $-13,56$ & 26.91 \\
US_List & 0.24 & 0.43 & 0.00 & 1.00 & 0.24 & 0.43 & 0.00 & 1.00 \\
SDRET & 6.63 & 52.11 & 0.00 & 579.29 & 4.31 & 18.11 & 0.00 & 199.95 \\
Year & 0.00 & 0.00 & 0.00 & 0.00 & 1.00 & 0.00 & 1.00 & 1.00 \\
\hline
\end{tabular}

Source: Prepared by the authors.

We can observe that the average of the natural log of firms' Size shows only a slight increase, which demonstrates that the total assets of these firms has no great increase between 2010 and 2012. Meanwhile, firms' Leverage has an average increase between the two periods, from 25.26 (2010) to 30.43 (2012), indicating that companies are assuming greater risks with more leveraged business.

On the other hand, the variable Change, which is the percentage of alteration in the earnings per share (EPS) of year $(t-1)$ for the year $t$, has a reduction in the mean from 0.35 to 0.29 , and an increase in the standard deviation from 2.49 to 3.12, from 2010 to 2012, respectively. These results suggest that there is greater volatility in earnings per share of companies between 2011 and 2012 than between 2009 and 2010 .

The variable Signal, which indicates if the earnings per share (EPS), is negative in the year $(t+1)$ and positive in year $t$, suggesting the occurrence of a non-recurring loss in the firm, has also a significant average reduction, from 0.11 in 2010 to 0.03 in 2012.

The firms' indicator of the Shares Daily Returns Standard Deviation shows a considerable reduction in its standard deviation, decreasing from 52.11 in 2010 to 18.11 in 2012. This indicates a lower volatility in stock prices, and may lead to a more accurate forecast in the second period.

\subsection{Disclosure Indexes}

The descriptive statistics for the disclosure index is demonstrated in Table 6. 
Table 6 - Descriptive Statistics for the Disclosure Index

\begin{tabular}{|c|c|c|c|c|c|c|c|c|}
\hline \multirow[t]{2}{*}{ Disclosure Index } & \multicolumn{4}{|c|}{2010} & \multicolumn{4}{|c|}{2012} \\
\hline & $\begin{array}{c}\text { Mea } \\
n\end{array}$ & S.D. & Min & Max & Mean & S.D. & Min & Max \\
\hline $\begin{array}{l}\text { Model } 1 \text { (Dichotomous- } \\
\text { Strict) }\end{array}$ & 0.198 & 0.055 & 0.070 & 0.354 & 0.199 & 0.051 & 0.066 & 0.312 \\
\hline $\begin{array}{l}\text { Model } 2 \text { (Dichotomous- } \\
\text { Tolerant) }\end{array}$ & 0.266 & 0.058 & 0.137 & 0.397 & 0.281 & 0.054 & 0.158 & 0.418 \\
\hline $\begin{array}{l}\text { Model } 3 \text { (Partial } \\
\text { Compliance-Strict) }\end{array}$ & 0.275 & 0.057 & 0.141 & 0.430 & 0.288 & 0.058 & 0.120 & 0.402 \\
\hline $\begin{array}{l}\text { Model } 4 \text { (Partial } \\
\text { Compliance-Tolerant) }\end{array}$ & 0.375 & 0.061 & 0.181 & 0.518 & 0.485 & 0.049 & 0.338 & 0.638 \\
\hline
\end{tabular}

Source: Prepared by the authors.

It can be seen that, in both years, whenever we apply the partial unweighted approach (that gives equal weights to each standard) the compliance level is higher than when we apply the dichotomous approach (that gives equal weights to each disclosure item and, indirectly, gives higher weights to standards that require more disclosure items). This indicates that, in the Brazilian context, the greater the number of disclosure items required by a standard, the lower tends to be the percentage of items disclosed by firms, suggesting that firms tend to be more selective in disclosing if the standard requires a high number of items to be disclosed.

Analyzing the disclosure compliance index trend over the years, we can see almost no change when model 1 is applied (mean and standard deviation of $19.82 \%$ and $5.55 \%$ in 2010 , and of $19.95 \%$ and $5.08 \%$ in 2012 , respectively), a slight improvement when models 2 or 3 are applied, and a significant advance only when model 4 is used (mean and standard deviation of $37.46 \%$ and $6.13 \%$ in 2010 , and of $48.48 \%$ and $4.88 \%$ in 2012 , respectively). This means that, if we were strict in establishing the applicability of a standard to a firm and/or gave equal weight to each required disclosure item (regardless of the number of items required by the standard), it has been little improvement on the firms' disclosure compliance level in Brazil over the years. Only if we were very tolerant in measuring the disclosure compliance index (by both coding as not applicable the standards for which a firm omit information about their application, and indirectly giving higher weight to standards that require less disclosure items) we can see a significant improvement over the years.

These results are consistent with the findings of Santos et al. (2014), which studied the disclosure index for 366 Brazilian firms in 2010, and found a smaller average of $16.04 \%$ (Model 1) and a higher average of 33.72\% (Model 4). However, these findings are significantly lower than the findings of Hodgdon et al. (2008), in a sample of 87 firms worldwide (most of them European), that apply IFRS in their financial reports of 1999 and 2000: firms lowest average was 55\% (unweighted score) and the highest average was 68\% (weighted score). 


\subsection{Hypothesis Analysis}

Table 7 presents the results summary of the defined regression, which tests the hypothesis studied in this research, using the four metrics for the disclosure compliance index previously defined.

Table 7 - Regression Analyses for Four Models of Disclosure Index (Dependent Variable $=$ Forecasting Error)

\begin{tabular}{|c|c|c|c|c|c|}
\hline Variables & & $\begin{array}{c}\text { Disclosure } \\
\text { Index } 1 \\
\text { (Dichotomous- } \\
\text { Strict) }\end{array}$ & $\begin{array}{c}\text { Disclosure Index } \\
\mathbf{2} \\
\text { (Dichotomous- } \\
\text { Tolerant) }\end{array}$ & $\begin{array}{c}\text { Disclosure Index } \\
\mathbf{3} \\
\text { (Partial } \\
\text { Compliance- } \\
\text { Strict) } \\
\end{array}$ & $\begin{array}{c}\text { Disclosure Index } \\
\mathbf{4} \\
\text { (Partial } \\
\text { Compliance- } \\
\text { Tolerant) } \\
\end{array}$ \\
\hline \multirow[t]{2}{*}{ Constant } & & 22.33 & 19.13 & 22.17 & 22.84 \\
\hline & & (0.18) & $(0.26)$ & (0.19) & (0.20) \\
\hline \multirow{2}{*}{ LNSIZE } & $(-)$ & $-9.29(*)$ & -8.24 & $-9.02\left(^{*}\right)$ & -8.60 \\
\hline & & $(0.08)$ & $(0.12)$ & $(0.08)$ & $(0.11)$ \\
\hline \multirow[t]{2}{*}{ LNSIZE2 } & $(+)$ & $0.79(* *)$ & $0.71\left(^{*}\right)$ & $0.76\left(^{*}\right)$ & $0.74\left(^{*}\right)$ \\
\hline & & $(0.05)$ & $(0.08)$ & $(0.06)$ & $(0.08)$ \\
\hline \multirow[t]{2}{*}{ SIGN } & $(+)$ & $1.05\left(^{* *}\right)$ & $1.05\left(^{* *}\right)$ & $1.04(* *)$ & $1.10\left({ }^{* *}\right)$ \\
\hline & & $(0.04)$ & $(0.04)$ & $(0.05)$ & $(0.04)$ \\
\hline \multirow[t]{2}{*}{ LNCHANGE } & $(+)$ & 0.08 & 0.06 & 0.09 & 0.08 \\
\hline & & $(0.56)$ & $(0.63)$ & $(0.52)$ & $(0.56)$ \\
\hline \multirow[t]{2}{*}{ LNCHANGE2 } & $(+/-)$ & 0.04 & 0.04 & 0.04 & 0.04 \\
\hline & & $(0.26)$ & (0.32) & $(0.30)$ & $(0.27)$ \\
\hline \multirow[t]{2}{*}{ LNLEVERAGE } & $(+)$ & 0.12 & 0.11 & 0.08 & 0.13 \\
\hline & & $(0.56)$ & $(0.58)$ & $(0.71)$ & $(0.54)$ \\
\hline \multirow[t]{2}{*}{ LNLEVERAGE2 } & $(+/-)$ & 0.04 & 0.04 & 0.04 & 0.02 \\
\hline & & $(0.43)$ & $(0.41)$ & $(0.35)$ & (0.62) \\
\hline \multirow[t]{2}{*}{ LNSDRET } & $(+)$ & -0.45 & -0.44 & -0.46 & -0.44 \\
\hline & & (0.13) & $(0.14)$ & $(0.12)$ & $(0.14)$ \\
\hline \multirow[t]{2}{*}{ LNSDRET2 } & $(+/-)$ & 0.15 & 0.15 & 0.16 & 0.14 \\
\hline & & (0.22) & $(0.23)$ & (0.19) & $(0.28)$ \\
\hline \multirow[t]{2}{*}{ YEAR } & & 0.04 & 0.12 & 0.13 & 0.00 \\
\hline & & (0.87) & $(0.62)$ & $(0.58)$ & $(1.00)$ \\
\hline \multirow[t]{2}{*}{ LNDISCn } & $(-)$ & $-1.42(* *)$ & -1.56 & $-1.68(*)$ & 0.18 \\
\hline & & $(0.05)$ & $(0.14)$ & $(0.07)$ & $(0.87)$ \\
\hline R2 & & 0.1416 & 0.1299 & 0.1382 & 0.1126 \\
\hline $\mathrm{F}$ & & $1.68\left(^{*}\right)$ & 1.52 & $1.63\left(^{*}\right)$ & 1.29 \\
\hline
\end{tabular}

Source: Prepared by the authors. $\left({ }^{*}\right),\left({ }^{* *}\right)$ and $\left({ }^{* * *}\right)$ indicate that the estimated coefficient is statistically significant at the 10 percent, 5 percent, and 1 percent levels, respectively. In parenthesis: the $\mathrm{p}$-value of the estimated coefficients.

In order to identify which model of panel data, the fixed effect or the random effect model, fits better with the collected data, we perform the Hausman's Test (WOOLDRIDGE, 2006), and find that, for all disclosure indexes, the fixed effect model has better adhesion, given that in all cases the $\mathrm{p}$-values are lower than 0.05 .

The regression results using the models 1 and 3 for measuring the disclosure compliance levels support our hypothesis (respectively, at the $5 \%$ and at the $10 \%$ 
level), that is, the higher the compliance level of Brazilian firms with IFRS disclosure requirements, the lesser tends to be the analysts' earnings forecast errors.

These results are consistent with other studies' evidence (ASHBAUGH and PINCUS, 2001; HOPE, 2003a, 2003b; HODGDON et al., 2008), finding that disclosure is an important determinant of analysts' forecast accuracy. This suggests that increasing levels of compliance with IFRS disclosure requirements provide more useful information to financial analysts, leading to an improvement in the accuracy of earnings forecasts and to better market targeting in the firms' evaluation.

In addition, we find that the disclosure index is statistically significant only when we use the stricter approach in determining the applicability of a standard to a firm (models 1 and 3). This reinforces the idea that the metric with greater explanatory power for the variation in the accuracy of analysts' forecasts is the one that codes as zero compliance when the firm omits information about the applicability of a standard to it, certainly because this behavior can induce the users of financial statements to erroneously believe that the firm does not have the kind of transaction referred by the standard. Furthermore, considering both the criteria for establishing the applicability of a standard to a firm (strict or tolerant) and the approach to accumulate the overall disclosure index (if by disclosure required item or by standard), the model that best explain analysts' forecasts accuracy is the stricter one, which results in the lowest disclosure compliance mean (model 1, with mean of 19.82\% in 2010 and of $19.95 \%$ in 2012, and p-value of 0.05 in the regression). The converse is also true, that is, the model that least explains forecasts accuracy is the one that results in the highest disclosure index mean (model 4, with mean of $37.46 \%$ in 2010 and of $48.48 \%$ in 2012 , and p-value of 0.87 in the regression).

This indicates that, in the Brazilian context, the disclosure compliance calculated more strictly has greater influence over the analysts' forecasting accuracy than the score calculated in a more tolerant form, suggesting that firms should be more explicit in reporting the applicability of a standard to them in order to enjoy the economic benefits associated with the higher accuracy of analysts' forecasts.

Among the control variables, Signal and Size present also potential explanatory over the analysts' forecasting errors, consistently with prior studies. The variable Signal has a positive relationship with forecasting errors in all the four regressions (among 1.04 to 1.10, all of which significant at the $5 \%$ level), reaffirming that when the firm' earnings change from positive to negative, the surprise factor occurs and the analysts forecasting errors tends to be greater. The variable Size has a negative relationship with analysts' forecast errors, confirming that the higher the size of the firm, the lower the forecasting error: the linear form of the variable Size (LNSIZE) is significant (at the $10 \%$ level) only in the first and third regression models, but its quadratic form (LNSIZE2) is significant in all the four regression models (at the 5\% percent level in model 1 and at the $10 \%$ level in the others). 


\section{CONCLUSIONS}

We analyze the influence of firms' compliance with IFRS required disclosure on analysts' earnings forecast errors in the Brazilian context. We examine whether and to what extent the variance in the Brazilian firms' disclosure compliance levels in the Notes to financial statements of the years 2010 and 2012 affects analysts' earnings forecast errors for the years 2011 and 2013, respectively.

For measuring the firms' compliance level with IFRS disclosure requirements we follow the four disclosure compliance metrics used by Santos et al. (2014), and find overall disclosure compliance levels far below the levels found in other countries. The overall disclosure compliance level we find for Brazilian firms range from around $20 \%$ to $48 \%$ (depending on the metric used), while the disclosure levels found by Hodgdon et al. (2008), mainly for Continental European firms a decade before (1999 and 2000), range from 55\% to $68 \%$.

By using the analysts' consensus from I/B/E/S results from panel data with fixed-effects we identify a significant negative relationship between firms' disclosure compliance levels (measured accordingly to the two stricter models) and the analysts' earnings forecast errors. We control this finding for other factors that influence the forecasting error, as explored in previous studies.

This result is consistent with other studies (ASHBAUGH and PINCUS, 2001; HOPE 2003a, 2003b; HODGDON et al., 2008) finding that disclosure is an important determinant of analysts' forecast accuracy. This suggests that increasing levels of compliance with IFRS disclosure requirements improve the information usefulness to financial analysts, leading to an increase in the accuracy of earnings forecasts and to a better targeting of the market in firms' evaluation, thus contributing to reduce the informational asymmetry between firms' managers and market investors.

Our findings are particularly important to highlight the usefulness of the disclosures required by IFRS for analysts' forecasts, mainly in current days, when the effectiveness of current IFRS disclosure policies is being questioned worldwide, leading the IASB to revisit this issue (IFRS, 2013).

This study contributes to better understanding the effects of IFRS adoption in Brazil on analysts' forecast accuracy, since the two studies (PESSOTI, 2012; GATSIOS, 2013) that examine this question use only binary variables to identify analysts' forecasts error before and after the IFRS adoption, and obtain diverging results. Our findings, by confirming that higher analysts' accuracy is associated with higher IFRS disclosure compliance levels, reinforce the idea that firms' compliance with IFRS disclosure requirements is at least as important as an alleged IFRS adoption per se.

Our findings may also be a contribution from a national environment to international research on this topic, as they emerge from the interaction of conditions that can hinder transparency (code-law tradition, a less efficient capital market and insufficient enforcement) that result in quite lower firms' compliance levels with IFRS required disclosure, compared to that found in more developed markets. Thus, in line with Verrecchia (2001), who pointed out the advantages to study less efficient markets, Brazil's accounting environment seems 
to be especially interesting to study the distinction between alleged IFRS adoption versus actual firms' compliance with IFRS required disclosure.

Our results suggest that, although a less favorable environment for transparency could reduce the overall perception of the IFRS adoption benefits to financial market, these benefits seem to be better enjoyed by firms that engage more seriously in complying with the IFRS requirements. That is, the market seems to be able to distinguish and reward firms that excel in compliance with IFRS, even in a general atmosphere of low compliance.

Thus, a practical implication of these findings for Brazilian listed firms is the refutation of some critics that the IFRS adoption would have led to an excess of information that adds no value. On the contrary, our findings suggest that the firm's effort to meet IFRS disclosure requirements creates value, as it leads to smaller analysts forecasting errors and, therefore, to a lower stock price volatility, reducing risk and capital costs.

Besides, by attesting that in the Brazilian context only stricter metrics of disclosure compliance have explanatory power on analysts' forecast errors, our findings have a practical implication, suggesting that firms should be more explicit in disclosing the applicability of a standard to them in order to better obtain the economic benefits associated with the higher accuracy of analysts' forecasts.

Finally, it is worth to emphasize some limitations that should be considered when assessing the results of this study, such as: (i) the sample of firms (123) is small and can contain selection problems; (ii) although the disclosure index is built on mandatory disclosure items under IFRS, being some disclosure required items a matter of professional judgment, it is impossible to completely eliminate the researcher subjectivity in verifying the firm' compliance scores; (iii) the use of panel data with only two periods, as this is the simplest way to use panel data and it is sufficient only for analysis with fixed effects; and (iv) the use of analysts' consensus (the average estimate by firm) to calculate forecast errors, without controlling for possible analysts' bias.

\section{REFERENCES}

AKERLOF, G. A. The market for "lemons": Quality uncertainty and the market mechanism. The quarterly journal of economics, p. 488-500, 1970.

ASHBAUGH, H.; PINCUS, M. Domestic accounting standards, international accounting standards, and the predictability of earnings. Journal of Accounting Research, vol. 39, n. 3, p. 417-434, 2001.

BARRON, O. E.; KILE, C. O.; O'KEEFE, T. B. MD\&A quality as measured by the SEC and analysts' earnings forecasts. Contemporary Accounting Research, vol. 16, n. 1, p. 75-109, 1999.

BARTH, M. E.; LANDSMAN, W. R.; LANG, M. H. International accounting standards and accounting quality. Journal of Accounting Research, vol. 46, n. 3, p. 467-498, 2008.

BRASIL. Lei n. ${ }^{\circ} 11.638$, de 28 de dezembro de 2007. Altera e revoga dispositivos da Lei n. ${ }^{\circ}$ 6.404, de 15 de dezembro de 1976, e da Lei n. ${ }^{\circ}$ 6.385, de 7 de 
dezembro de 1976, e estende às sociedades de grande porte disposições relativas à elaboração e divulgação de demonstrações financeiras. Retrieved May, 03, 2015 in http://www.planalto.gov.br/ccivil/_Ato2007-2010/2007/ Lei/L11638.htm.

CHRISTENSEN, H. B.; LEE, E.; WALKER, M.; ZENG, C. Incentives or standards: What determines accounting quality changes around IFRS adoption? European

Accounting Review, vol. 24, n. 1, p. 31-61, 2015.

CHOI, F. D. S., FROST, C. A., MEEK, G. K. International Accounting. 7rd. Ed. New Jersey: Prentice Hall, 2011.

Comissão de Valores Mobiliários - CVM. Deliberação CVM n. ${ }^{\circ}$ 604, de 19 de novembro de 2009. Retrieved May, 03, 2015 in:

http://www.cvm.gov.br/asp/cvmwww/atos/Atos_Redir.asp?Tipo=D\&File=\%5Cdeli \%5Cdeli604.doc.

COOKE, T. E. The impact of size, stock market listing and industry type on disclosure in the annual reports of Japanese listed corporations. Accounting and Business Research, vol. 22, n. 87, p. 229-237, 1992.

CUIJPERS, R.; BUIJINK, W. Voluntary adoption of non-local GAAP in the European Union: a study of determinants and consequences. European Accounting Review, vol. 14, n. 3, p. 487-524, 2005.

DA SILVA, H. A capacidade previsionária no mercado acionário brasileiro - Um estudo focado nas previsões dos analistas de investimentos. In: Encontro Nacional da Associação Nacional de Pós-Graduação em Pesquisa em Administração, 22, 1998. Anais... Foz do Iguaçu: ENANPAD, 1998.

DASKE, H.; GEBHARDT, G. International financial reporting standards and experts' perceptions of disclosure quality. Abacus, vol. 42, n. 3-4, p. 461-498, 2006.

DASKE, H.; HAIL, L.; LEUZ, C.; VERDI, R. Adopting a label: heterogeneity in the consequences of IFRS adoptions. Journal of Accounting Research, vol. 51, n. 3, p. 495-547, 2013.

DYE, R. A. Mandatory versus voluntary disclosures: the cases financial and real externalities. The Accounting Review, vol. 65, n. 1, p. 1-24, 1990.

An evaluation of "essays on disclosure" and the disclosure literature in accounting. Journal of Accounting and Economics, vol. 32, n. 1, p. 181-235, 2001.

FAMA, E. F. Efficient Capital Markets: A Review of theory and empirical Work. The Journal of Finance, vol. 25, n. 2, p. $383-417,1970$.

GATSIOS, R. C. Acurácia e dispersão das estimativas dos analistas no mercado de capitais brasileiro: Impacto da adoção do padrão IFRS sobre a qualidade preditiva da informação contábil. Tese (Doutorado em Controladoria e Contabilidade). Curso de Pós-graduação em Contabilidade e Controladoria, Faculdade de Economia, Administração e Contabilidade, Universidade de São Paulo, São Paulo, 2013.

GLAUM, M.; BAETGE, J.; GROTHE, A.; OBERDORSTER, T. Introduction of International Financial Standards, disclosure quality and accuracy of analysts' earnings forecasts. European Accounting Review, vol. 22, n. 1, p. 79-116, 2013. 
HEALY, P. M.; PALEPU, K. G. Information asymmetry, corporate disclosure, and the capital markets: A review of the empirical disclosure literature. Journal of Accounting, Economics, vol. 31, n. 1-3, p. 405-440, 2001.

HODGDON C.; TONDKAR, R. H.; HARLESS, D. W.; ADHIKARI, A. Compliance with IFRS disclosure requirements and individual analysts forecast errors. Journal of International Accounting, Auditing and Taxation, vol. 17, n. 1, p. 1-13, 2008.

HOPE, O. K. Disclosure practices, enforcement of accounting standards, and analysts' forecast accuracy: An international study. Journal of Accounting Research, vol. 41, n. 2, p. 235-273, 2003a.

Accounting policy disclosures and analysts' forecasts. Contemporary Accounting Research, vol. 20, n. 2, p. 295-321, $2003 \mathrm{~b}$.

HUSSAIN, S. The impact of segment definition on the accuracy of analysts' earnings forecasts. Accounting and Business Research, vol. 27, n. 2, p. 145-156, 1997.

IFRS Foundation. Discussion forum - Financial reporting disclosure. Feedback Statement. Retrieved May, 30, 2013 from

http://www.ifrs.org/Alerts/PressRelease/Documents/2013/Feedback-StatementDiscussion-Forum-Financial-Reporting-Disclosure-May-2013.pdf

IFRS Foundation. IFRS around the world - Jurisdictional Profile: Brazil. Retrieve in January, 05, 2016 from http://www.ifrs.org/Use-around-the-

world/Documents/Jurisdiction-profiles/Brazil-IFRS-Profile.pdf, 2015.

JENSEN, M. C., MECKLING, W. H. Theory of the firm: managerial behavior, agency costs and ownership structure. Journal of Financial Economics, vol. 3, n. 4, p. 305360, 1976.

JIAO, T.; KONING, M.; MERTENS, G.; ROOSEMBOOM, P. Mandatory IFRS adoption and its impact on analysts' forecasts. International Review of Financial Analysis, vol. 21, n. 2012, p. 56-63, 2012.

LANG, M.; LUNDHOLM, R. Corporate disclosure policy and analyst behavior. The Accounting Review, vol. 71, n. 4, p. 467-492, 1996.

LA PORTA, R.; LOPEZ-DE-SILANES, F.; SHLEIFER, A.; VISHNY, R. Investor protection and corporate governance. Journal of Financial Economics, vol. 58, n. 1, p. 3-27, 2000.

LEUZ, C.; VERRECCHIA, R. E. The Economic Consequences of Increased

Disclosure. Journal of Accounting Research, vol. 38, Supplement, p. 91-124, 2000.

MARTINEZ, A. L. Analisando os analistas: estudo empírico das projeções de lucros e das recomendações dos analistas do mercado de capitais para as empresas brasileiras de capital aberto. 2004. Tese (Doutorado em Administração). Curso de Pós-graduação em Administração da Escola de Administração de Empresas de São Paulo da Fundação Getúlio Vargas, São Paulo, 2004.

MEEK, G. K.; THOMAS, W. B. A review of markets-based international accounting research. Journal of International Accounting Research, vol. 3, n. 1, p. 21-41, 2004. 
MAPURANGA, P. V. R.; PONTE, V. M. R.; COELHO, A. C. D.; MENESES, A. F. Determinantes do nível de disclosure de instrumentos financeiros derivativos em firmas brasileiras. Revista Contabilidade e Finanças, vol. 22, n. 57, p. 263-278, 2011.

PESSOTTI, T. Impacto da convergência às Normas Contábeis Internacionais de Contabilidade sobre a Acurácia dos Analistas do Mercado de Capitais Brasileiro. 2012. Dissertação (Mestrado em Contabilidade). Fundação Instituto Capixaba de Pesquisas em Contabilidade, Economia e Finanças, Vitória, 2012.

SANTOS, E. S.; PONTE, V. M. R.; MAPURANGA, P. V. R. Mandatory IFRS Adoption in Brazil (2010): Index of Compliance with Disclosure Requirements and some Explanatory Factors of Firms Reporting. Revista de Contabilidade e Finanças, vol. 25, n. 65, p. 161-176, 2014a.

STREET, D. L.; GRAY, S. J.; BRYANT, S. M. Acceptance and observance of international accounting standards: An empirical study of companies claiming to comply with IASs. The International Journal of Accounting, vol. 34, n. 1, p. 11-48, 1999.

STREET, D. L.; GRAY. S. J. Factors influencing the extent of corporate compliance with International Accounting Standards: summary of a research monography. Journal of International Accounting, Auditing and Taxation, vol. 11, n. 1, p. 51-76, 2002.

TSALAVOUTAS, I.; EVANS, L.; SMITH, M. Comparison of two methods or measuring compliance with IFRS mandatory disclosure requirements. Journal of Applied Accounting Research, vol. 11, n. 3, p. 213-228, 2010.

VAN TENDELOO, B.; VANSTRAELEN, A. Earnings management under German GAAP versus IFRS. European Accounting Review, vol. 14, n. 1, p. 155-180, 2005.

VANSTRAELEN, A.; ZARZESKI, M.T.; ROBB, S. W. G. Corporate nonfinancial disclosure practices and financial analyst forecast ability across three European countries. Journal of International Financial Management \& Accounting, vol. 14, n. 3, p. 249-278, 2003.

VERRECCHIA, R. E. Essays on disclosure. Journal of Accounting and Economics, vol. 32, n. 1-3, p. 97-180, 2001.

WOOLDRIDGE, J. M. Introdução à econometria: uma abordagem moderna. São Paulo: Pioneira Thomson Learning, 2006. 